AFRICAN

\title{
Forum: At the Gates of Heaven
}

by Paul Tembe* Centre for Chinese Studies, University of Stellenbosch Stellenbosch, South Africa

\section{Introduction}

Since the Hong Kong SAR handover to China the region has experienced perennial protests, culminating in the 'Umbrella Revolution' in September 2014. The majority of observers, reporters and analysts have tended to frame the events as a war between democratic and communist forces. Overlooked is a deeper struggle between two visions of social order, with Hong Kong protesters advocating individual freedoms and the Mainland insisting on 'unity' under the framework of a 'harmonious society' spanning greater China. At the heart of the protests are the mistrusts laden in the rhetoric each party uses to make its case. The following discussion examines some of the contradictions embedded in Hong Kong's Basic Law and proceeds to highlight the repository of shared Chinese cultural norms, collectively spanning both Hong Kong and Mainland China, which could potentially function as tools of reconciliation.

\section{The framework for the current Hong Kong SAR - Central Government rela- tions}

The legal and political framework for relations between the Hong Kong SAR and the Central Government rely on the 'One country, two systems' policy of the PRC promulgated in 1983 by the NPC, adopted to "realise the peaceful reunification of

*Paul Tembe is a Research Fellow at the Centre for Chinese Studies at the University of Stellenbosch in Stellenbosch, South Africa. 
AFFAIRS

the country" and the Hong Kong Basic Law (The practice of the 'One Country, Two systems' policy, June 10, 2014, Foreword). The former stipulates the principles based on Article (31) of the 1982 PRC constitution and the latter is the product of the Sino-British Joint Declaration signed in 1984, (Roda, 1997). What does the policy of 'One country two systems' policy and the Hong Kong Basic Law entail? Both afford the Hong Kong SAR greater autonomy in all matters of governing a state except for the areas of defence and foreign relations (Section 3(2) of the Sino-British Joint Declaration). According to the Sino-British Joint Declaration which stipulates conditions of the handover of Hong Kong SAR to China, the Central Government has a mandate to recommend relevant aspects of governing the region (ibid.). The Hong Kong Basic Law also provides constitutional protection on various fundamental human rights and freedoms. Specifically, the International Covenant on Civil and Political Rights is given a constitutional status through the basic laws (ibid.).

A reading of the two framework documents that serves to govern the Hong Kong SAR reveals possible internal contradictions. The contradictions are highlighted by the following questions: i) what is the discourse that informs the logic of 'One country, two systems' policy and ii) how is such policy congruent to the framework of the Sino-British Joint Declaration? In answering these questions the next section analyses parts of the latest publication of 'The Practice of the "One Country, Two Systems" Policy in the Hong Kong Special Administrative Region. ${ }^{1}$ The publication is the latest edition stipulating the practice of the 'One Country, Two systems' policy (June 10, 2014). Furthermore, the document in its conclusion uses similar rhetoric as that applied in response to the recent Hong Kong SAR protests (Chen, 2013). The publication in its conclusion tends to shift the blame of the Hong Kong SAR disturbances on foreign actors rather than provide an outline of the successes and failures of the 'One Country, Two systems' policy. It reads as follows:

"It is necessary to stay alert to the attempt of outside forces to use Hong Kong to interfere in China's domestic affairs, and prevent and repel the attempt 


\section{AFRICAN \\ EAST-ASIAN \\ AFFAIRS

made by a very small number of people who act in collusion with outside forces to interfere with the implementation of "one country, two systems" in Hong Kong. " ['The Practice of the 'One Country, Two systems' policy (June 10, 2014, p. 53)]

The above statement supposes that disturbances and conflicts between the Central Government and Hong Kong protesters are propelled by foreign instigators ('China Restricts Voting Reforms for Hong Kong 'Buckley and Forsythe. ASIA PACIFIC, AUG. 31, 2014.). The statement reads as a sign of limited vision by the Central Government in assuming that the Hong Kong people have no ability to galvanize a popular movement unless propelled by 'hostile' Western powers. What the Central Government needs to do is to understand the rationale and conditions that constitute the construction of conformity acts of the Hong Kong SAR. The customary defense mechanism by the Central Government manifest in the Mainland does not seem to carry much traction in the Hong Kong SAR.

\section{Analysis of contradictions in the Hong Kong Basic Law framework}

The first discernible controversy in the Hong Kong Basic Law framework seems to be based on the source of authority for the Hong Kong SAR Basic Law (Pattie, 2008). Some experts claim that the Basic Law is meant for the domestic rule of Hong Kong, deriving its authority from the Constitution of the PRC while other players argue that it derives authority directly from the Sino-British Joint Declaration (ibid.). ${ }^{2}$ Viewed in accordance with the first argument the PRC has a larger share of authority to change the Hong Kong Basic Law (ibid.). On the other hand, the Hong Kong courts have a limited ability to challenge the PRC domestic legislation (Schneider, 2002). In short, the Basic Law is authorized by the PRC's National People's Congress.

The limited spaces for the practice of the Hong Kong Basic law seem to be exasperated by the bias inherent through the implementation of the 'One Country, two systems' policy as far as it favours the Central Government's veto power. Such is discernible in regard to Article (159) of the Hong Kong SAR Basic Law which stipu- 
AFFAIRS

lates aspects related to the amendment of the Basic Law. Article (159) of the Basic Law assures the Central Government power to veto any amendments that are not in congruence with any of the principles of the 'One Country, two systems' policy. The second example is that stipulated in item (4) of the 'Nine Principles of 1983', which states that "The principal officials (of the Hong Kong Regional Government) would be selected by election through consultations held locally and be appointed by the Central People's Government."3

In the issue of delaying the contents of Article (45), i.e. the latest timetable for electing the Chief Executive in 2017 through universal suffrage, the chairman of the PRC's government Law Committee, Qiao Xiaoyang stated that the decision should be based upon the motto, "love China and Hong Kong" and "not to oppose the Central Government" (Chen, 2013). The meaning of such a statement is fully understandable to those versed in the PRC revolutionary rhetoric but to the uninitiated, it is vague and smacks of arrogance. The issue at hand is not why a government official uttered such a vague statement or how it affects the implementation of universal suffrage in the Hong Kong SAR. Instead, it is how statements of such importance are framed and how they are understood by the Hong Kong populace?

In accordance with how Article (159) on the amendment of Basic Law is handled, it would seem that the honours for aligning the discourse between the two parties are in the hands of the Central Government. The above mentioned article reads as "The power of amendment of the Basic Law shall be vested in the NPC" (see the Constitution of the PRC, Article (32) and the 'One Country, two systems' policy documents). It further states that "No amendment to the Basic Law shall contravene the established basic policies of the PRC regarding Hong Kong" (The statement is made in reference to the 'One Country, two systems' Policy document. Cited from "Interpretation And Amendment Of The Basic Law" (2014). In practice any amendment to the Hong Kong Basic Law needs the Chief Executive to have the final say while all recommendations must first pass the Legislative Council and the NPC. In the case where amendment is initiated in Hong Kong SAR it 


\section{AFRICAN \\ EAST-ASIAN \\ AFFAIRS

must be approved by the NPC. In both cases the decision to amend the Basic Law is in the hands of the NPC (see Hong Kong Basic Law, Article (158)).

A further difficulty in amending the Hong Kong Basic Law, besides those inherent in the veto powers of the NPC, is discernible in the ambiguity inherent in Articles (45) and (68). The above mentioned articles reflect on the possibility of implementing universal suffrage through the "Principle of gradual and orderly progress" and "in light of the actual situation" respectively. The articles lack specifics on conditions and timeframe for implementing universal suffrage in the territory. Such ambiguity was used by law experts in Mainland China when arguing against the 2007 and 2008 universal suffrage election of the Chief Executive (Davis, 2013). ${ }^{4}$ They pointed out that such a move would violate the "Principle of gradual and orderly progress" and "in light of the actual situation" set forth in Articles (45) and (68) respectively (ibid). The Standing Committee of the National People's Congress eventually ruled against the possibility of universal suffrage in 2007 and 2008 on 26 April 2004 (ibid.). The possibility of universal suffrage was not totally cancelled but was moved to the year 2017 (Tan, 2008). The approaching date for the implementation of universal suffrage, the year 2017, coupled with the previous unfulfilled promises may be the cause of the recent throes and pre-emptive strikes from both sides of the conflict. Viewed in such a manner, it is highly possible that, the nearer the election for the next Chief Executive, the more escalation of the Hong Kong protests. The Annex (1), point (7) of the Basic Law may read as a delaying tactic that is long overdue; it does not seem to hold anymore in view of the current protests in the Hong Kong SAR.

The Annex (I), point (7) of the Basic Law articulates amendments on the election of the Chief Executive as follows:

"If there is a need to amend the method for selecting the Chief Executives for the terms subsequent to the year 2007, such amendments must be made with the endorsement of a two-thirds majority of all the members of the Legislative Council and the consent of the Chief Executive, and they shall be reported to the Standing Committee of the National People's Congress for approval" (2006) 
AFFAIRS

The annex has so far not been challenged by any other amendment to the Basic Law. The recent protests have to be viewed as part of pre-emptive strikes from both sides with the NPC releasing a document that sets the tone and pace for the methods of electing the next Chief Executive in three years ("NPC decision on Hong Kong's constitutional developments - 2014".). The Hong Kong protesters on the other hand, have launched a pre-emptive attack not awaiting the response of the Legislative Council on the matter but instead resorting to civil disobedience. ${ }^{5}$

The above mentioned articles of the Hong Kong Basic Law are not the only ones that reflect contradictions towards the 'One country, two systems' policy. A fundamental aspect that may be at the heart of conflicts between the Hong Kong SAR and the Central Government is discernible in the arguments of the 'Article 45 Concern Group' (Hong Kong Democratic Foundation, 2014). The group engages the Central Government from within the Hong Kong Legislative Council challenging the ambiguity of both Articles (45) and (68) (Tong, 2013). In engaging the Central Government the group promotes debates on universal suffrage from a legal and constitutional point of view (ibid.). The form of debate as promoted by the 'Article 45 Concern Group' points at the implementation of the 'rule of law' as opposed to the 'rule of men' or 'rule by law'. ${ }^{6}$

The suggestion that there exists distrust between the two parties is apparent in view of the Hong Kong protestors reaction to the suggestions made by the Central Government through the "NPC decision on Hong Kong's constitutional developments - 2014" document of the year 2014. Reading of the document shows that the Central Government merely made suggestions towards the development of the Hong Kong SAR constitution and that the process was to involve public consultation.

"All the Joint Declaration said is that the Chief Executive will be 'appointed by the Central People's Government on the basis of the results of elections or consultations to be held locally [in Hong Kong]." [Summers, (CNN, October, 2014)] 


\section{AFRICAN \\ EAST-ASIAN \\ AFFAIRS \\ THE CHINA MONITOR}

According to the above analysis there exist deep seated contradictions in the language and interpretations of the two documents that serve as framework for the Hong Kong SAR Basic Law. Such contradictions are inherent in the discourses that each party used to articulate its freedoms in ridding themselves of the colonial and imperialist forces.

\section{The making of political discourse - conformity acts in the PRC}

The presentation in the previous sections reflects that the crucial component of the conflict is a world view embedded in the Maoist Chinese and British traditions or constitutionalism. The majority of the expressions used to legitimate the party and the Central Government in the Mainland PRC today are those rationalized during the Yan'an revolutionary years, 1936 to 1948 (Selden, 1995; Apter and Saich, 1998). The Mainland population was educated on the use of revolutionary expressions during the continuous revolutionary campaigns of the 1930s to the late 1970s. Greater parts of expressions used during the revolution were borrowed from traditional Chinese language stock ( $\mathrm{Li}, 1$ 1957; Hsia, 1950; Chuang 1960). Some of the expressions are used in their original traditional form and others were re-engineered to suit the purpose of the revolution ( $\mathrm{Ji}, 2004)$. The use of correct language in the Mainland still carries immense political capital which reflects on a society that despite rapid economic growth continues to be mainly, 'logocentric,' (Apter and Saich, 1994) or a society of 'politics in front' (Dittmer, 1986).

During the 1930s to the 1980s the Hong Kong status quo did not tolerate the language used by the Chinese Communist Party as such was regarded as communist propaganda and the 'language of the enemy'. The formalized converted traditional language as used in the PRC's revolutionary discourse was not relevant either for those fighting for independence in the Hong Kong region. While Mainland China was promoting collectivist, all-encompassing slogans such as 'Serving the People' wei renmin fuwu and 'Wholeheartedly Serving the People' quanxin quanyi wei remin fuwu for articulating the way forward for the revolution and for establishing a better society, the Hong Kong people were engaged in a fight against the British rule. The fight of the Hong Kong people was articulated in the rhetoric that was in 
AFFAIRS

stuck contrast to that adopted by the PRC revolution. As a result, to this day, the type of the rhetoric that the two parties use in rationalizing and articulating the ideals of their respective societies read to the other as 'the language of the enemy', a persisting manifestation of the Cold War era. ${ }^{7}$

The PRC, having undergone a series of revolutions, had until recently mastered the art of limiting, if not avoiding, the emergence of insurrectionary acts on the Mainland. In the cases where any form of insurrection had arisen, it was countered by the use of the standard tools from the revolutionary era. ${ }^{8}$ The use of these materials continues to this day and serves to counter the rhetoric that is regarded by the Central Government as the language that is not proper. Proper language according to the present status quo in the PRC is that which is framed within the wellchoreographed narrative of the Chinese revolution. The latest maxim used for such purposes is that in line with the notion of rejuvenating the Chinese nation under the /slogan 'China Dream', 中国梦 zhongguo meng. ${ }^{9}$ Schoenhals (1992), points out that the Beijing Central Government has spared no effort in mastering the production of the 'correct and proper' discourse focusing on perlocutionary acts to ensure 'proper practice' in society and sustainability of the status quo. Such status quo is sustained through prescription and proscription of language in all sectors of society (ibid.). As a result, the Mainland populace responds to instructions mapped by such language as second nature. Even in instances when private individuals sometimes recognize the ambiguity of such language they have lived to learn what it means. Bourdieu (1991) terms such awareness as the 'knowledge of the game' that is, when individuals know how to harvest capital even from the most obscured type of local political jargon. The local people always have a way of reading between the lines (Chang, 1991). A reflection of such practice may be read in the contemporary Chinese saying “上有政策下有对策” which loosely translates as 'People can always find a way to cope with the government policies. ${ }^{10}$

However, the Hong Kong populace has a different take on the Central Government's rhetoric in the region. Since the return to the PRC the Central Government 


\section{AFRICAN \\ EAST-ASIAN \\ AFFAIRS

faces problems as the tools used for prescription and proscriptions of language in the Mainland China seem to fail when confronted by the Hong Kong protest movement's rhetoric. Such a scenario may be summarised as that, the Mainland PRC conformity acts, read as insurrectionary acts in the Hong Kong SAR.

\section{The collectivist family value system}

While much of the debate on the Hong Kong issue focuses on issues of modern history - British colonialism, Chinese socialism and the legal and discursive battles which have stemmed from them, it is often overlooked that both parties share a much deeper cultural repository, with its own customary laws.

A crucial element in this regard is the Chinese familial value system. Scholars from diverse disciplines and varying perspectives tend to regard China as a collectivist society which adheres to familial value system (Earley, 1994; Gelfand, 1995). In China, the logic of such a family is replicated and used as a model for a centralized form of governance where the state serves as parent and its people as children (Boden, 2009; Varall, 2013; Tembe, 2013). Furthermore, it is difficult if not impossible for an outsider to determine where the lines of a private family and those of a greater national one separate in China. In China it is normal to hear individuals refer to the entire nation as if it were one family.

One specific character of a collectivist society is the preference for inclusion as opposed to exclusion (Hofstede, 1994). What are particular characteristics of the Chinese family that differ from other cultures in its serving as a foundational field of inculcation and transfer of traditions, values and norms of society? ${ }^{11}$ The answer to the above question is that in China, relationships, values and hierarchies witnessed in traditional and private family are replicated in the practice of governing the entire nation. The above discussed traits are shared by all the regions of greater China including Hong Kong SAR, albeit applied differently in regards to political activism and the running of government. Such traits are embodied in the slogan: 国是大家, 家是小国“A nation consist of everyone, a family is a small nation”11. 
AFFAIRS

Such definition of the Chinese family is that which lays a foundation for all practice throughout the Chinese cultural realm (Tembe, 2013). The Chinese family serves almost as a philosophical unit where the word family includes other dimensions that signify a (homeland) guojia 国家, (individuals) renjia 人家, (homestead) jia 家, (everyone) dajia 大家 and (family members) or (clan) jiaren 家人 (Tembe, 2013; cf. Giskin, H. and Walsh, B. 2001). The sharing of the word jia 家 by all the above entities may perhaps offer a window into the mind-set of members that constitute the Chinese family. ${ }^{13}$

According to the above description of family, the Hong Kong region handover to the PRC would then translate to the return of long lost child. If so, can a parent (the Central Government), ignore values and patterns of rhetoric Hong Kong inherited during the hundred and fifty years of colonial rule? Viewed in such a manner the conflicts between Hong Kong protesters and the Central Government are merely growing pains of the 'One country two systems' policy. Far from being an expression of 'orientalism' (Said,1979 \& 1994), such a view is an attempt at arguing that, despite the hundred and fifty years of Hong Kong region absence from greater China there are strong cultural and linguistic similarities which favour reconciliatory efforts and understanding between the two parties. However, ignoring the differences manifest in the rhetoric used to articulate the ideals of the two regions would be tantamount to inviting further conflicts and the rise of perennial protests that would do little to benefit the entire China region even when manifest within the context of civil society. ${ }^{14}$ In conclusion there is a deeper Chinese tradition shared by both the Hong Kong SAR and the Mainland China. Instead of promoting the Chinese family values in their original sense, the Central Government focuses on the hierarchical aspects of the concepts which translate into an act of bullying.

\section{Praxis of conflict resolution in China}

The logic of the above presented family system has potential to resolve the crises 


\section{AFRICAN \\ EAST-ASIAN \\ AFFAIRS

between the Hong Kong SAR and the Central Government. Such a suggestion requires the Central Government to abandon its customary manner in regards to conflict resolution. Conflict resolution in Mainland China is practiced in a top-down manner (Diamant, 2000), while emphasizing the rhetoric of 'serving the people' (Tembe, 2013). The practice is reflective of a centralized state system where the final word lies with those highest in the hierarchy (Lam, 2013). Such framework may be functional in a society where the parent child relation manifest in a private traditional family is replicated for the practice of government (Giskin, 2001). The practice of governing a nation using the logic of a parent-child relationship requires unquestioned loyalty and total obedience to one's social unit where the price of diversion is isolation and shame (ibid.). Such practice when applied to the entire nation translates into the manifestation of the highest order of collectivism where failure to conform to the will of the majority may lead to loss of political, cultural, social and even economic capital (Tembe, 2013). ${ }^{15}$ As there is pressure in society to preserve honour and the 'face' of the group to which one belongs, be it that of kin or professional nature, individuals tend to adhere to the top-down patterns of practice (Nevis,1983). In order to navigate such a space an individual requires constant selfcensorship and a strong reliance on precedence (Schoenhals, 2007; cf. Munro, 1996). Such precedence may be mapped into three different categories serving the same purpose: that of individuals conforming to the will of the many, in accordance with the notion of gong/si (public/private) (Tembe, 2013). The first category is that in which an individual may search for precedence from senior family members, reflecting on the manifestation of the da/xiao big/small complementary dualism. In the second category precedence is sought from senior school or work colleagues, a reflection of the nei/wai (inner/outer) logic. The third, precedence is sought from the vast trope of traditional Chinese fairy tales, allegories, and idioms and from constantly used four character sayings (Ji, 2004; Lagerwey, 2010; Lee, 1978; Tembe, 2013; Walsh, 1997; Yip, 1982).

Given the above framework for government the claims of fake democracy as cried by many pro-democracy entities in Hong Kong and the world may be impossible to perceive for Mainland China whose value system is dependent on precedence, total 
AFFAIRS

obedience and unquestionable loyalty to a collective. In China, plurality is regarded with suspicion and may as well translate as anarchy which threatens the very foundation upon which the entire society is built (Wang, 2013). The people of Hong Kong SAR on the other hand, have overtime managed to create a space for a private individual without threatening the needs of the collective. China in attempting to prevent the manifestation of Western values in its territory has to avoid coercion but instead attempt to fine tune its tools for co-opting Hong Kong back into greater China. In short, with the colonists long gone from the region the Central Government must bear the brunt of healing the Hong Kong society.

\section{Reconciliation as the foundation for preventing future conflicts}

Reconciliation ought to serve as a tool for continued social development, a framework for establishing peaceful relations and co-existence (Lerche, 2000). Such line of thought is particularly relevant to China whose familial value system espouses 'harmony' as the bedrock of society (Callahan, 2012). In Chinese society 'harmony' as a cultural value has acquired the status of an 'empty signifier' where in some instances 'cooperation' is undermined. ${ }^{16}$ Under such circumstances conformity is achieved not through consensus but from reverence to the traditional notion of 'harmony'. ${ }^{17}$ Such role of harmony may be misleading where its assumed traditional value undermines everyday realities and practices of the greater mass. The tendency may serve to undermine peace efforts to the point of generating conflicts when attempted to regions outside Mainland China. The notion of 'harmony' hexie needs to extend beyond the discursive confines of political sloganeering. Instead, it needs to be founded on practical aspects of 'cooperation' hezuo in all spheres of society and free from prescription and proscription dictated by the dogma of the status quo. ${ }^{18}$

The lexical terms, 'harmony' hexie and 'cooperation' hezuo, are expressions at the centre of the Chinese family value system and manifest as instruments for 'limiting the game', which serve to perpetuate ethical dualism (Tembe, 2013). It has been observed that notions of ethical dualism tend to profess to one version of reality and events making no room for expression of different views and ideas. 


\section{AFRICAN \\ EAST-ASIAN \\ AFFAIRS

Such tendencies may suggest that only one historical point of view or version of truth is the correct one. In China, the concepts of 'harmony' and 'cooperation' as manifest in political discourse, act as the 'end game' in themselves rather than instruments for peaceful coexistence. Callahan (2012) points out that 'harmony in diversity', contrary to that espoused by Confucius encourages different opinions, values and norms giving room for cooperation. ${ }^{19}$ Callahan further states that the type of harmony that serves to limit the game is similar to that invoked by China's political leaders and its public intellectuals as a way of describing Chinese visions of future world order. He concludes that such logic reflects the Sino-centric world order of the future, where peace can become "pacifying," and harmony can become "harmonizing." The limitations and connections between 'harmony' and 'cooperation' as manifest in the Mainland political rhetoric may be discerned in definitions by Keohane (1984). Keohane defines cooperation as "actions of separate individuals and organizations being brought into conformity with one another through a process of negotiation" and warns that pre-existing harmony does not ensure stability (cited in Lerche, 2000.). The definition suggests an extended role of the notion of harmony beyond that of 'limiting the game' or serving as a tool for conformity manifest in a top-down manner. Instead, the definition suggests interactive and intersocietal meanings of the concept harmony where consensus is reached through discussion and mass based participation.

\section{Conclusion}

The above discussion illustrates that the conflict between the Hong Kong SAR and the Central Government is arrested at differing interpretations of the 'One country, two systems' policy and of the Hong Kong SAR Basic Law. It has also suggested an alternative platform for the analysis of the Hong Kong SAR - Central Government conflict beyond the customary framework of a stand-off between the democratic and communist 'oppressive' forces. The discussion has suggested a potential solution based on reconciliatory processes in the rhetoric and interpretation of the concepts of 'harmony' and 'unity' meant for governing the Hong Kong SAR. Such a view is based on the observation that the tools used by the Central Government in the Main- 
AFRICAN

AFFAIRS

land do not take in the Hong Kong SAR, as evidenced by the recurring conflicts in the region. The Hong Kong region, although sharing cultural values with the Mainland it has not experienced the string of political education campaigns that frame the type of rhetoric used by its counterpart. Ignoring the current Hong Kong discursive norms as practiced through civil disobedience would only lead to discord and continued unrest in the region.

\section{Endnotes}

${ }^{1}$ The document "The Practice of the "One Country, Two Systems" Policy in the Hong Kong Special Administrative Region. 2014' was released in October in the mist of the on-going Hong Kong protests and may have fuelled further unrest for the protesters.

${ }^{2}$ Cursive style marks emphasis from the original text.

${ }^{3}$ The veto and the delays in the using the universal suffrage as methods for the elections of the Legislative Council members and the Chief Executive have had support from Article (159) with the support of the 'Nine Principles' as stipulated in the 'One Country, two systems Policy'.

${ }^{4}$ Article (45) reads as follows:

" The Chief Executive of the Hong Kong Special Administrative Region shall be selected by election or through consultations held locally and be appointed by the Central People's Government."

"The method for selecting the Chief Executive shall be specified in the light of the actual situation in the Hong Kong Special Administrative Region and in accordance with the principle of gradual and orderly progress. The ultimate aim is the selection of the Chief Executive by universal suffrage upon nomination by a broadly representative nominating committee in accordance with democratic procedures." (See the Hong Kong Basic Law). 


\section{AFRICAN \\ EAST-ASIAN \\ AFFAIRS

${ }^{5}$ The Occupy Central Movement did not consult with the LEGCO, instead it demands immediate implementation of universal suffrage, entirely abandoning the premises of "gradual" and "orderly" introduction of rights in the Hong Kong SAR as stipulated in the Basic Law, Articles (45) and (68).

${ }^{6}$ The scenario might be that which points at tendencies of the "Rule of Man" overriding the 'Rule of Law'.

${ }^{7}$ The persistence of the Cold War rhetoric is reflected on the 'democratic versus communist forces stand-off' framework used by the majority of the observers and analysts for analysing the recent Hong Kong protests.

${ }^{8}$ The Laosanpian, Traditional Chinese classical tales, Revolutionary speeches and slogans constitute some of the standard tools used for the purpose of quelling dissent in the Mainland China.

${ }^{9}$ The Zhongguo meng China Dream is representative of the current President $\mathrm{Xi}$ Jinping time of office.

${ }^{10}$ The expression is reflective of the ever present game of 'cat and mouse' manifest in the Chinese art of government. The expression has its origins in the two traditional Chinese concepts, i) saving face and ii) preference to consensus rather than confrontation. See Zhang (2010) on examples how the notion of the 'middle road' and 'saving face' are practiced by the government and ordinary people in their everyday endeavours.

11 The question is imperative when considering that all cultures of the world use family setting to transmit cultural values, norms, rules and traditions from present to the future. Family serves as a primary field for the processes of inculcation of values and laying foundations for the prevailing habitus.

12 The saying may be encountered in various settings of everyday language used in both institutionalized and popular culture.

${ }^{13}$ In its macro sense as in 国家 (homeland). 
AFFAIRS

${ }^{14}$ Such logic may sound similar to the Central Government rhetoric that 'The Hong Kong demonstrations are a public nuisance' but in this instance it is meant to show that the protests manifest not as a norm but as representative of the Hong Kong SAR populace result to protect the identity of the region.

${ }^{15}$ Such notion reflects ethical dualism as manifest in the notion of the $g o n g / s i$ (public/private) lexical pairs where public takes primacy over the private and doubling as a representative of all that is correct and desirable in society.

${ }^{16}$ The term 'empty signifier' was coined by Lévi-Strauss to explain words that have indefinite meaning, such as 'mana', 'freedom', and 'liberty'. Lévi-Strauss states that these words have meanings that are indefinable in the sense that although they cannot be defined as tangible, they come to take on larger meanings that encompass powerful feelings and values. Ernesto Laclau's study Emancipation(s) (1996) uses the idea of the 'empty signifier' to refer to absent social rights and values.

${ }^{17}$ One such example is when the notion of harmony features as a slogan representative of a political ideal, as in the case of 'harmonious society' 和谐hexie shehui. In China, such use of the lexical term 'harmony' limits its meanings to those of reverence to powers that be, or serves to reflect loyalty to one's country and people.

${ }^{18}$ The lexical term hezuo tends to feature as an auxiliary in the rhetoric that promotes the notion of 'harmonious society' 和谐hexie shehui.

${ }^{19}$ Confucius discusses the harmony/sameness (he/tong) distinction that is found throughout classical Chinese literature: "The exemplary person harmonizes with others, but does not necessarily agree with them (he er butong); the small person agrees with others, but is not harmonious with them." (The Analects 13/23). 
AFRICAN

EAST-ASIAN

AFFAIRS

\section{Bibliography}

Althusser, L. 1971. "Lenin and philosophy and other essays" Ideology and Ideological State Apparatuses. Monthly Review, 127-186.

Apter, D. \& Saich, T. 1994. Revolutionary discourse in Mao's republic. Cambridge, Mass: Harvard University Press.

Austin, J. L. 1975. How to do things with words. William James lectures. 2d ed. Vol. 1955. Oxford Eng: Clarendon Press.

Baker, H. 1979. Chinese family and kinship. Macmillan: London.

Boden, J. 2009. The Wall Behind China's Open Door - Towards Efficient Intercultural Management in China. Belgium: Academic and Scientific Publishers.

Bourdieu, P. 1977. Outline of a theory of practice. R. Nice (tr.). Cambridge. New York: Cambridge University Press.

Bourdieu, P. 1990. The logic of practice. R. Nice (tr.). Cambridge.

Bourdieu. P. and Thompson, B. 1991. Language and symbolic power [Ce que parler veut dire. English]. Cambridge: Polity Press.

Bourdieu. P. 2000. Pascalian Meditations. R. Nice (tr.).Stanford, California: Stanford University Press.

Bohannan, P. 1995. How culture works. New York: New York Free Press.

Butler, J. 1997. Excitable speech: A politics of the performative. New York: Routledge.

Jawitz, J. 1995. Performance in first- and second-year engineering at UCT. South African Journal of Higher Education, 9(1):101-108.

Cao, D. 1999. "Ought to" as a Chinese Legal Performative? International Journal for the Semiotics of Law 12: 153-169. Kluwer Academic Publishers.

Cao, W. 2010. Modern Chinese Vocabulary Studies. 曹炜著《现代汉语词汇研 
AFRICAN

AFFAIRS

究》。暨南大学出版社. Jinan University Publishing.

Chang, K. and Owen, S. (eds.). 2010. The Cambridge history of Chinese literature. "Yan'an and the Rectification Campaign". Cambridge: Cambridge University Press.

Che, W-K. 1979. The modern Chinese family. R \& E Research Associates, INC. Palo Alto, California.

Chen, T.P. 2013. 'Hong Kong's Future Leader Must 'Love China' China Real Time. Mar 26. Available. [Online]: http://blogs.wsj.com/ chinarealtime/2013/03/26/hong-kongs-future-leader-must-love-china/. [2014, December 10].

Davis, M. 2013. 'Screening is not the way to 'love China, love Hong Kong'.' South China Morning Post. April, 2013. Available. [Online]: http:// www.scmp.com/news/hong-kong/article/1215483/screening-not-way-lovechina-love-hong-kong/. [2014, November 24].

Derrida, J. 1977. "Signature event context” glyph. Johns Hopkins Textual Studies, 1: 172-97.

Diamant, N. 2000. 'Conflict and Conflict Resolution in China: Beyond MediationCentered Approaches.' Journal of Conflict Resolution, 44(4): 523-546.

Elizabeth, C. 2014. China's Imperial President - Xi Jinping Tightens His Grip. Foreign Affairs. Published by The Council on Foreign Relations. Available [Online]: http://www.foreignaffairs.com/articles/142201/elizabeth-ceconomy/chinas-imperial-president/ [2014, November 10].

Evans, R. 2012. Chinese 'Patriotic' Education Draws Protesters in Hong Kong. BloombergBusiness.com. Available. [Online]: http://www.bloomberg.com/ news/2012-07-29/chinese-nationalistic-education-draws-protesters-in-hong -kong.html. [2014, July 30].

Feng, Y. 1937. History of Chinese Philosophy. Peiping: Henri Vetch. 
AFRICAN

EAST-ASIAN

AFFAIRS

Giskin, H. \& Walsh, B. 2001. An introduction to Chinese culture through family. Albany: State University of New York Press.

Guo, Y., Tian, J., Yang, L. \& Wang, Q. 2008. Keywords for better understanding China. Foreign Language Press. Beijing.

Guilford, G. 2014. The Secret History of Hong Kong's Democratic Stalemate. The Atlantic. 14 October. Available. [Online]: http://www.theatlantic.com/ international/archive/2014/10/the-secret-history-of-hong-kongs-democraticstalemate/381424/. [2014, October 22].

Hansen, C. 1992. A Daoist theory of Chinese thought: a philosophical interpretation. New York: Oxford University Press.

Hillier, J. \& Rooksby, E. 2005. Habitus: A sense of place. Aldershot: Ashgate.

Hsia, T. 1961. Metaphor, Myth, Ritual and the People's Commune. Studies in Chinese communist terminology; no. 7. Berkeley: Centre for Chinese Studies, Institute of International Studies, University of California.

Huss, A. 2000. Old Tales Retold: Contemporary Chinese Fiction and the Classical Tradition. Columbia University.

Ji, F. 2004. Linguistic engineering: Language and politics in Mao's china. Honolulu: University of Hawai'i Press.

Lagerwey, J. and Kalinowski, M. (eds.).2009. Early Chinese religion. Part.1, Shang through Han (1250 BC-220 AD). Leiden. Boston: Brill.

Lagerwey, J. \& Lü P. (eds.) 2010. Early Chinese religion. Part 2, The period of division (220-589 AD) Leiden. Boston: Brill.

Lagerwey, J. 2010. China: A Religious State. Hong Kong: Hong Kong University Press.

Lakoff, G. \& Johnson, M. 2003. Metaphors we live by. University of Chicago Press. Lam, W. 2013. "Centralized power key to Xi's 'China dream"” Asia Times Online. 02 
AFRICAN

AFFAIRS

April. Available. [Online]: http://www.atimes.com/atimes/China/CHIN-01020413.html. [2014, October 22].

Lau, D. C. 1958. The Treatment of Opposites in 'Tzŭ' 老 子. Bulletin of the

School of Oriental and African Studies, University of London, 21(1/3): 344 -360 .

Lau, D. C. 1963. Lao Tzu: Tao Te Ching. Penguin Classics: United Kingdom.

Li, C. 1956. Preliminary Study of Selected Terms. Studies in Chinese Communist Terminology. no. 1. East Asia Studies, Institute of International Studies. University of California Berkeley, California.

Li, C. 1957. Literary and colloquial terms in new usage; Terms topped by numerals. Studies in Chinese Communist Terminology. no. 3. East Asia Studies, Institute of International Studies. University of California Berkeley, California.

Lindsberg, et al. 2009. Tradition \& Adaptation in Chinese Family Enterprise. HSBC.

Knapp, K. 2005. Selfless offspring: filial children and social order in medieval China. Honolulu: University of Hawai'i Press.

Munro, D. 1996. The imperial style of inquiry in twentieth-century China: The emergence of new approaches. Michigan monographs in Chinese studies. 72(1). Ann Arbor: Centre for Chinese Studies, University of Michigan.

Pickle, L. 2001. Written and spoken Chinese: Expression of culture and heritage. In Giskin, H. and Walsh, B. 2001. An introduction to Chinese culture through family. Albany: State University of New York Press.

Said, E.W. 1978. Orientalism. New York: Pantheon.

Schneider, 2002. David v. Goliath: 'The Hong Kong Courts and China's National People's Congress Standing Committee.' Berkeley Journal of International Law. 20(3): Article 3. 
AFRICAN

Schoenhals, M. 1992. Doing things with words in Chinese politics: five studies.

Berkeley: Centre for Chinese Studies, Institute of East Asian Studies, University of California.

Schoenhals, M. 2007. 'Demonising Discourse in Mao Zedong's China: People vs Non-People.' Totalitarian Movements and Political Religions. 8 (3-4): 465482 .

Selden, M. 1995. China in revolution: the Yenan way revisited. Armonk: M.E. Sharpe.

Shinn, D. \& Eisenman, J. 2012. China and Africa - A Century of Engagement. University of Pennsylvania Press.

Spence, J. 1999. The Search for Modern China. New York: Norton.

Summers, T. Available. [Online]: http://edition.cnn.com/2014/10/07/opinion/hongkong-britain-china-summers/ [2014, November 10].

Wang, C. 2002. Words that kill: Calling for the destruction of "class enemies" in China, 1949-1953. East Asia, history, politics, sociology, culture. New York: Routledge.

Wang, Z. A. 2013. Process and Pluralism: Chinese Thought on the Harmony of Diversity (Process Thought). Ontos Verlag.

Web, J., Schirato, T. \& Danaher, G. 2002. Understanding Bourdieu. Sage Publications.

Yan, W. 2000. A Critical Analysis of Three of Mao's Early Political Essays. In D. Heisey (ed.). Chinese Communication Perspectives. Stamford, Connecticut: Ablex Pub. Corp.

Zedong, M. 1968. Laosanpian. Beijing.

Zhou, S. \& Zhou, X. 2004. "Deng Xiaoping's "two aspects" and the construction of spiritual civilization." Hebei spirit civilization network 520: 13. Tieling Agri- 
cultural Vocational and Technical College.

Tembe, P. 2013. Reevaluating Political Performatives of the PRC: Maoist Discourse - The Historical Trajectory of the Laosanpian. Centre for China Studies, The Chinese University of Hong Kong. Available. [Online]: http:// etheses.lib.cuhk.edu.hk/pdf/1008045090.pdf_[2014, January 5].

Varrall, M. 'Chinese diplomacy - the people as the state' China Studies Centre, Policy Paper Series, Paper 5. Macquarie University Sydney/Vrije Universiteit Amsterdam.

Wang, Z. 2013. "Not Rising, But Rejuvenating: The "Chinese Dream." The Diplomat. Available. [Online]: http://thediplomat.com/2013/02/chinese-dreamdraft/3/ [2014, October 20]. 